\title{
Analisis Kondisi Sosial Ekonomi Keluarga terhadap Kesejahteraan Keluarga di Gampong Karang Anyar Kota Langsa
}

\author{
Nurlaila Hanum \\ Prodi Ekonomi Pembangunan Fakultas Ekonomi Universitas Samudra \\ e-mail:nurlailahanum@unsam.ac.id \\ Safuridar \\ Prodi Ekonomi Pembangunan Fakultas Ekonomi Universitas Samudra \\ e-mail:safuridar@unsam.ac.id
}

\begin{abstract}
Abstrak
Penelitian ini bertujuan untuk mengetahui kondisi sosial ekonomi keluarga terhadap kesejahteraan keluarga di Gampong Karang Anyar. Kondisi sosial ekonomi dilihat dari jumlah anggota keluarga dan pendapatan sedangkan kesejahteraan keluarga dilihat dari konsumsi. Data yang digunakan adalah data primer yang bersumber dari responden penelitian sebanyak 81 orang, dan dianalisis menggunakan regresi linier berganda. Hasil pengujian membuktikan bahwa secara parsial, jumlah anggota keluarga ataupun pendapatan memiliki pengaruh yang positif dan signifikan terhadap kesejahteraan atau konsumsi keluarga. Secara simultan, hasil pengujian membuktikan bahwa jumlah anggota keluarga dan pendapatan berpengaruh signifikan terhadap kesejahteraan atau konsumsi pada masyarakat Gampong Karang Anyar Kota Langsa.
\end{abstract}

Kata kunci: Sosial ekonomi keluarga, jumlah anggota keluarga, pendapatan.

\section{PENDAHULUAN}

Kesejahteraan masyarakat salah satunya dapat dilihat dari keadaan atau kondisi sosial ekonomi keluarga. Kondisi sosial ekonomi keluarga merupakan kondisi setiap keluarga dalam masyarakat yang dilihat dari tingkat pendidikan, pendapatan, pekerjaan, dan jumlah anggota keluarga yang dinilai akan memberikan dampak terhadap kesejahteraan masyarakat dan kesejahteraan keluarga dalam ruang lingkup paling kecil di masyarakat.

Kondisi sosial ekonomi yang dilihat dari pendapatan memberikan dampak terhadap kesejahteraan. Pendapatan yang diterima setiap individu atau keluarga secara umum bersumber dari hasil pekerjaan yang dilakukannya. Pendapatan yang lebih besar dari tingkat konsumsi memberikan arti bahwa keluarga itu memiliki tingkat kesejahteraan, sedangkan bagi yang memiliki pendapatan kecil akan memberikan dampak terhadap kurang sejahteranya keluarga.
Selain pendapatan, kondisi sosial ekonomi keluarga dapat diketahui dari jumlah anggota keluarga. Jumlah anggota dalam sebuah keluarga memberikan dampak juga terhadap kesejahteraan keluarga. Semakin besar jumlah anggota dalam sebuah keluarga semakin besar tingkat kebutuhan, dan bila pendapatan tidak mendukung, akan memberi dampak kurang sejahteranya keluarga karena tidak mencukupi kebutuhan dalam keluarga. Kemudian jumlah anggota keluarga yang menjadi tanggungan bila sedikit dan pendapatan yang besar memberikan dampak terhadap kesejahteraan keluarga.

Keluarga yang sejahtera merupakan keluarga yang dapat memenuhi segala kebutuhannya, dan disebut sebagai keluarga berkualitas, dengan terpenuhinya kebutuhan dalam aspek pendidikan, kesehatan, ekonomi, sosial budaya, kemandirian keluarga dan mental spiritual serta nilai-nilai agama. Dalam sebuah keluarga untuk memenuhi kebutuhan 
erat dengan besaran pendapatan yang dihasilkan dari pekerjaan dan dikeluarkan sebagai bentuk konsumsi untuk mencapai kesejahteraan. Dapat diartikan bahwa pendapatan dan konsumsi merupakan variabel sederhana yang menentukan kesejahteraan, karena baik secara individu maupun rumah tangga dapat digunakan untuk mencapai kesejahteraan manusia. Konsumsi keluarga merupakan salah satu kegiatan ekonomi keluarga untuk memenuhi berbagai kebutuhan barang dan jasa. Dari komoditi yang dikonsumsi keluarga akan memiliki kepuasan tersendiri. Oleh karenanya, konsumsi dapat dijadikan sebagai indikator kesejahteraan keluarga.

Gampong Karang Anyar sebagai salah satu gampong yang ada di Kecamatan Langsa Baro Pemerintah Kota Langsa memiliki masyarakat yang heterogen dan memiliki kondisi sosial ekonomi yang bervariasi dan tingkat kesejahteraan keluarga yang berbedabeda. Berdasarkan hasil penelitian awal yang dilakukan pada 10 keluarga di Gampong Karang Anyar, diperoleh data sebanyak 2 orang kepala keluarga memiliki pekerjaan sebagai Pegawai Negeri Sipil, 1 orang Polisi dan 1 orang TNI dan 2 orang Pegawai Negeri Sipil serta 1 orang polisi tersebut, istri juga bekerja sebagai Pegawai Negeri Sipil. Dari keempat keluarga tersebut memiliki pendapatan tetap setiap bulannya, akan tetapi dari keempat keluarga memiliki jumlah anggota keluarga antara 6-8 orang, sehingga tingkat kesejahteraan yang dilihat dari tingkat konsumsi masih ada kebutuhan sekunder yang belum dapat terpenuhi. Kemudian 2 orang keluarga lainnya memiliki pekerjaan sebagai karyawan pada perkebunan dengan pendapatan menurut mereka tetap dan jumlah anggota keluarga sebanyak 5-7 orang dan konsumsi keluarga belum sepenuhnya terpenuhi. Selanjutnya 4 orang lainnya memiliki pekerjaan sebagai petani dan memiliki pendapatan yang tidak tetap dan jumlah anggota dalam keluarga antara 5-7 orang, karena pendapatan yang tidak menentu maka tingkat konsumsi disesuaikan dengan kondisi keuangan keluarga.
Berdasarkan latar belakang penelitian dengan kondisi sosial ekonomi yang dilihat dari pendapatan dan jumlah anggota keluarga pada setiap keluarga di Gampong Karang Anyar yang bervariasi. Berdasarkan uraian tersebut, maka perumusan masalah dalam penelitian ini adalah apakah kondisi sosial ekonomi keluarga berpengaruh secara parsial dan simultan memiliki pengaruh terhadap kesejahteraan keluarga di Gampong Karang Anyar. Tujuan penelitian ini adalah untuk mengetahui pengaruh kondisi sosial ekonomi keluarga secara parsial dan simultan terhadap kesejahteraan keluarga di Gampong Karang Anyar.

\section{Kondisi Sosial Ekonomi}

Menurut Abdulsyani (2007), status sosial merupakan tempat seseorang secara umum di dalam masyarakatnya yang berhubungan dengan orang-orang lain, hubungan dengan orang lain dalam lingkungan pergaulannya, prestisenya dan hak-hak serta kewajibannya. Status sosial ekonomi menurut Soekanto (2007) berarti kedudukan suatu individu dan keluarga berdasarkan unsur-unsur ekonomi.

Menurut Abdulsyani (2007), status (kedudukan) memiliki dua aspek, yaitu aspek struktur dan aspek fungsional. Aspek yang pertama yaitu aspek struktural bersifat hierarkis, yang artinya aspek ini secara relatif mengandung perbandingan tinggi atau rendahnya terhadap status-status lain. Sedangkan aspek status yang kedua yaitu aspek fungsional atau peranan sosial yang berkaitan dengan status-status yang dimiliki seseorang. Kedudukan atau status berarti posisi atau tempat seseorang dalam sebuah kelompok sosial. Makin tinggi kedudukan seseorang maka makin mudah pula dalam memperoleh fasilitas yang diperlukan dan diinginkan.

\section{Faktor-Faktor yang Mempengaruhi Kondisi Sosial Ekonomi}

Menurut Sumardi (2004), untuk mengukur tingkat sosial ekonomi seseorang dari rumahnya, dapat dilihat dari: 
a. Status rumah yang ditempati. Status rumah bisa merupakan rumah sendiri, rumah dinas, menyewa rumah, menumpang pada saudara atau ikut orang lain.

b. Kondisi fisik bangunan. Kondisi fisik bisa berupa permanen, kayu dan bambu. Keluarga yang keadaan sosial ekonominya tinggi pada umumnya menempati rumah permanen, sedangkan keluarga yang keadaan sosial ekonominya menengah ke bawah lebih menggunakan semi permanen atau tidak permanen.

c. Besarnya rumah yang ditempati. Semakin luas rumah yang ditempati pada umumnya semakin tinggi tingkat sosial ekonominya. Rumah dapat mewujudkan suatu tingkat sosial ekonomi bagi keluarga yang menempati. Apabila rumah itu berbeda dalam hal ukuran kualitas rumah. Rumah yang dengan ukuran besar, permanen dan milik pribadi dapat menunjukkan bahwa kondiri sosial ekonominya tinggi. Berbeda dengan rumah yang kecil, semi permanen dan menyewa menunjukkan bahwa kondisi sosial ekonominya rendah.

\section{Pendapatan}

Case dan Fair (2007) menyebutkan bahwa pendapatan seseorang pada dasarnya berasal dari tiga macam sumber. Sumber pendapatan yang pertama bisa berasal dari upah atau gaji yang diterima sebagai imbalan tenaga kerja. Sumber pendapatan yang kedua bisa berasal dari hak milik yaitu modal, tanah, dan sebagainya. Sumber pendapatan yang ketiga bisa berasal dari pemerintah.

Sementara itu, Reksohadiprodjo (2000) mengkaitkan pendapatan dengan tingkat kesejahteraan keluarga, dan menyatakan argumen bahwa manusia menilai pekerjaan berdasarkan pada besaran upah dan kondisi kerja.

\section{Jumlah Tanggungan Keluarga}

Menurut Wirosuhardjo (2006), besarnya jumlah tanggungan keluarga akan bisa berpengaruh terhadap pendapatan. Hal ini karena semakin banyak jumlah tanggungan keluarga atau jumlah anggota keluarga yang ikut makan, maka secara tidak langsung akan memaksa tenaga kerja tersebut untuk mencari tambahan pendapatan. Sehingga dapat dinyatakan bahwa orang yang memiliki jumlah tanggungan keluarga yang cukup banyak, maka jumlah penghasilan yang dibutuhkan juga akan semakin besar. Apabila penghasilan yang dibutuhkan tidak cukup maka akan terjadi kemiskinan.

Para ahli ekonomi pada umumnya sependapat bahwa perkembangan jumlah penduduk dapat menjadi faktor pendorong maupun penghambat dalam pembangunan ekonomi. Sebagai faktor pendorong, karena perkembangan jumlah penduduk itu akan meningkatkan jumlah tenaga kerja, yang akhirnya dapat memperluas pasar. Akibat buruk yang mungkin ditimbulkan oleh perkembangan jumlah penduduk terhadap pembangunan adalah bila perkembangan tersebut dengan tingkat produktifitas yang tinggi maka akan terjadi pengangguran di masyarakat.

\section{Konsep Kesejahteraan Keluarga}

Menurut Kuswardinah (2007), keadaan sejahtera relatif berbeda pada setiap individu maupun keluarga dan ditentukan oleh falsafah hidup masing-masing. Kondisi sejahtera bersifat tidak tetap dan dapat berubah setiap saat baik dalam waktu cepat atau lambat. Untuk mencapai dan mempertahankan kesejahteraan manusia harus berusaha secara terus menerus dalam batas waktu yang tidak dapat ditentukan, sesuai dengan tuntutan hidup yang selalu berkembang dan tidak ada batasan waktunya.

Secara keseluruhan, konsep tentang kesejahteraan sangat beragam. Undangundang No. 52 Tahun 2009 menyatakan bahwa keluarga sejahtera adalah keluarga yang dibentuk berdasarkan perkawinan yang sah, mampu memenuhi kebutuhan hidup spiritual dan materil yang layak, bertakwa kepada Tuhan YME, dan memiliki hubungan serasi, selaras dan seimbang antara anggota dan antar keluarga dengan masyarakat dan lingkungan.

Puspawati (2013) menyatakan bahwa kesejahteraan tidak hanya berupa ukuran yang terlihat dan tidak terlihat, misalnya fisik, 
kesehatan dan spiritual. Lebih lanjut, kesejahteraan meliputi aspek-aspek berikut:

1. Economical well being; yaitu kesejahteraan ekonomi. Indikator yang digunakan adalah pendapatan (GNP, GDP, pendapatan per kapita per bulan, nilai asset).

2. Social well being; yaitu kesejahteraan sosial. Indikator yang digunakan antara lain tingkat pendidikan (SD/MI-SMP/ MTS-SMA/MA, PT, Pendidikan NonFormal Paket A, B, C; melek aksara atau buta aksara), dan status dan jenis pekerjaan (white collar adalah kaum elit/professional, atau blue collar yaitu kelompok proletar/ buruh pekerja); atau, punya pekerjaan tetap atau pengangguran).

3. Physical well being, yaitu kesejahteraan fisik. Indikator yang digunakan adalah status gizi, status kesehatan, tingkat mortalitas, dan tingkat mobilitas.

4. Psychological/spiritual mental, yaitu level kesejahteraan psikologi. Indikator yang digunakan adalah sakit jiwa, tingkat stress, tingkat bunuh diri, tingkat perceraian, tingkat aborsi, dan tingkat kriminal (perkosaan, perusakan, pencurian/ perampokan, penggunaan narkoba/napsa, penyiksaan/pembunuhan).

\section{Teori Konsumsi Pangan dan Non Pangan}

Menurut Mankiw (2006), konsumsi sebagai pembelanjaan barang dan jasa oleh rumah tangga. Barang yang dimaksud mencakup pembelanjaan rumah tangga pada barang yang tahan lama, kendaraan dan perlengkapan dan barang tidak tahan lama seperti makanan dan pakaian. Jasa mencakup barang yang tidak berwujud konkrit, termasuk pendidikan. Teori konsumsi dari Jhon Maynard Keynes mengedepankan variabel utama dalam analisinya yaitu konsumsi dipengaruhi oleh tingkat pendapatan $\mathrm{C}=\mathrm{f}(\mathrm{Y})$ (Mankiw, 2006). Keynes mengajukan tiga asumsi pokok secara makro dalam teorinya:

1. Kecenderungan mengkonsumsi marginal (marginal propensity to consume) ialah jumlah yang dikonsumsi dalam setiap tambahan pendapatan adalah antara 0-1.

2. Keynes menyatakan bahwa kecenderungan mengkonsumsi rata-rata (average prospensity to consume) turun ketika pendapatan naik.

3. Keynes berpendapat bahwa pendapatan merupakan determinan konsumsi yang penting dan tingkat bunga tidak memiliki peranan penting.

\section{Penelitian Sebelumnya}

Muflikhati et al. (2010), melakukan penelitian mengenai kondisi sosial ekonomi dan tingkat kesejahteraan keluarga, dengan studi kasus di wilayah pesisir Jawa Barat. Penelitian ini bertujuan untuk mengetahui pengaruh kondisi sosial ekonomi terhadap tingkat kesejahteraan keluarga di wilayah pesisir Jawa Barat. Metode penelitian menggunakan data cross sectional dengan jumlah sampel sebanyak 276 keluarga. Data yang diperoleh dianalisis dengan statitik inferensial. Hasil penelitian menunjukkan bahwa tidak terdapat perbedaan yang signifikan dalam hal umur ayah dan ibu, total aset, dan pengeluaran per kapita pada keluarga nelayan dan bukan nelayan. Akan tetapi, keluarga nelayan memiliki jumlah anggota keluarga dan pendapatan per kapita yang lebih besar secara signifikan daripada keluarga bukan nelayan. Sebaliknya, pendidikan ayah dan pendidikan ibu pada keluarga nelayan lebih rendah dibandingkan dengan pendidikan ayah dan ibu pada keluarga bukan nelayan. Nelayan lebih sejahtera dibandingkandengan keluarga bukan nelayan. Sebaliknya, jika kesejahteraan diukur dengan berbagai dimensi kehidupan, maka keluarga nelayan lebih rendah tingkat kesejahteraannya. Indikator yang memiliki sensitivitas dan spesifitas paling besar terhadap golden standard garis kemiskinan BPS untuk mengukur tingkat kesejahteraan keluarga di wilayah pesisir adalah indikator World Bank dan sosial metrik. Khusus untuk keluarga nelayan, indikator yang paling rendah biasnya terhadap garis kemiskinan BPS adalah indikator World Bank, BKKBN alasan ekonomi, dan sosial metrik. Kondisi sosial ekonomi yang berpengaruh signifikan terhadap kesejahteraan keluarga di wilayah pesisir berbeda sesuai dengan indikator yang digunakan. Akan tetapi, pada umumnya yang 
berpengaruh yaitu besar keluarga, pendidikan, aset, pendapatan, dan pengeluaran per kapita.

Nurwati (2008) melakukan penelitian mengenai pengaruh kondisi sosial dan ekonomi keluarga terhadap motivasi pekerja anak dalam membantu keluarga di Kabupaten Cirebon, Jawa Barat. Tujuan penelitian untuk mengkaji kontribusi yang diberikan oleh pekerja anak kepada keluarga, dan seberapa besar pengaruh variabel kondisi sosial dan ekonomi terhadap motivasi pekerja anak dalam membantu keluarga. Metode penelitian yang digunakan adalah explanatory research. Populasi dalam penelitian ini adalah anak yang berumur kurang dari 18 tahun yang bekerja di sektor industri (sektor formal). Jumlah sampel yang diambil sebagai responden sebanyak 165 pekerja anak. Hasil penelitian menunjukkan bahwa pengaruh kondisi ekonomi keluarga lebih dominan dibandingkan dengan pengaruh kondisi sosial keluarga terhadap motivasi pekerja anak dalam memberikan bantuan bagi keluarga.

\section{METODE PENELITIAN}

Populasi adalah wilayah generalisasi yang terdiri dari obyek/subyek yang mempunyai kualitas dan karakteristik tertentu yang ditetapkan oleh peneliti untuk dipelajari dan kemudian ditarik menjadi suatu kesimpulan (Sugiyono, 2010). Populasi dalam penelitian ini adalah keluarga yang ada di Gampong Karang Anyar dengan jumlah 432 keluarga.

Penelitian ini menggunakan sampel probabilitas, yaitu sampel mengandung arti bahwa setiap sampel dipilih berdasarkan prosedur seleksi dan memiliki peluang yang sama untuk dipilih, (Kuncoro, 2009). Tehnik pengambilan sampel menggunakan accidental sampling, yaitu pengambilan sampel secara kebetulan ditemui dan bersedia mengisi kuesioner maka dapat dijadikan sampel penelitian. Prosedur penarikan sampel atau besarnya sampel dilakukan menggunakan rumus Slovin yang dikemukakan oleh Sinulingga (2013), yaitu:

$$
\mathrm{n}=\frac{\mathrm{N}}{1+\mathrm{Ne}^{2}}
$$

dimana $N$ adalah ukuran populasi, $n$ adalah ukuran sampel, serta $e$ adalah tingkat error.

Berdasarkan rumus tersebut, maka hasil perhitungan adalah:

$$
\mathrm{n}=\frac{432}{1+\left[432 \times(0,1)^{2}\right]}
$$

Apabila hasil perhitungan dibulatkan, makan diperoleh jumlah sampel yang digunakan dalam penelitian ini adalah sebanyak 81 keluarga.

\section{Metode Analisis Data}

Analisis data yang digunakan untuk mengetahui pengaruh kondisi sosial ekonomi terhadap kesejahteraan keluarga, yang dinyatakan dalam bentuk fungsi persamaan regresi linier berganda (Furqon, 2009), sebagai berikut:

$$
\mathrm{Y}=\beta_{0}+\beta_{1} \mathrm{X}_{1}+\beta_{2} \mathrm{X}_{2}+\beta_{3} \mathrm{X}_{3 \ldots . .}+\beta_{\mathrm{n}} \mathrm{X}_{\mathrm{n}}+\mathrm{e}
$$

dimana $Y$ adalah variabel terikat, $X$ adalah masing-masing variabel bebas, dan $\beta$ adalah koefisien regresi dari masing-masing variabel bebas, serta $e$ adalah tingkat error.

\section{HASIL ANALISIS \\ Hasil Penelitian}

Gampong Karang Anyar merupakan salah satu gampong yang ada di kecamatan Langsa Baro Kota Langsa. Karang Anyar merupakan Kecamatan Langsa baro dengan luas gampong $1,08 \mathrm{~km}^{2}$ atau $108 \mathrm{Ha}$. Masyarakat di Gampong Karang Anyar adalah masyarakat yang heterogen dengan penduduk beragam suku dengan dominan suku Jawa, kemudian suku Batak, suku Aceh dan suku lainnya.

Masyarakat di daerah ini memiliki pekerjaan yang bervariasi, diantaranya adalah pegawai, karyawan, petani, dan wiraswasta. Bagi masyarakat yang menjadi petani secara umum memiliki sawah sendiri sedangkan sebagian lainnya yang tidak memiliki sawah maka mereka akan menyewa pada pemilik sawah lain. Pekerjaan yang heterogen ini memberikan dampak pada tingkat pendapatan yang bervariasi. Pekerjaan sebagai pegawai memiliki pendapatan yang selalu stabil dengan perolehan tetap setiap bulannya. 
Demikian juga pada setiap yang bekerja di perusahaan sebagai karyawan, memiliki pendapatan tetap setiap bulannya. Sedangkan bagi mereka yang bekerja sebagai petani, memperoleh pengahsilan yang tidak tetap atau tergantung pada hasil pertanian. Bagi wiraswasta memiliki pendapatan dari hasil usaha yang dijalankan setiap harinya. Dengan demikian pendapatan setiap penduduk di Gampong Karang Anyar Kecamatan Langsa Baro bervariasi sesuai dengan jenis pekerjaan yang dijalankan.

\section{Pengaruh Kondisi Sosial Ekonomi terhadap Kesejahteraan Masyarakat di Gampong Karang Anyar}

Kondisi sosial ekonomi dapat diketahui dari tingkat pendapatan dan jumlah anggota keluarga yang menjadi variabel bebas pada penelitian ini, sedangkan kesejahteraan masyarakat dapat diketahui dari pengeluaran konsumsi primer dan sekunder sebagai variabel terikat pada penelitian ini. Untuk mengetahui tingkat pengaruh variabel bebas pendapatan perbulan dan jumlah anggota keluarga terhadap konsumsi ditunjukkan oleh persamaan regresi linier berganda yang terangkum dalam Tabel 1.

Berdasarkan Tabel adapat diketahui mengenai hasil persamaan regresi linier berganda sebagai berikut:

$\mathrm{Y}=1258447,865+422078,720 \mathrm{X}_{1}+0,346 \mathrm{X}_{2}$

Berdasarkan persamaan regresi linier di atas dapat dijelaskan bahwa Konstanta sebesar 1258447,865 menunjukkan bahwa tingkat kesejahteraan masyarakat Gampong Karang Anyar sebelum dipengaruhi oleh pendapatan dan jumlah anggota keluarga.

Koefisien regresi dari variabel bebas yang pertama $\left(b_{1}\right)$ sebesar 422078,720 menunjukkan bahwa variabel jumlah anggota keluarga memiliki pengaruh positif terhadap kesejahteraan; bila jumlah anggota keluarga meningkat per satu jiwa maka akan meningkatkan pengeluaran konsumsi sebesar Rp. 422.078,720, dengan asumsi variabel pendapatan dianggap konstan.

Koefisien regresi dari variabel bebas yang kedua $\left(b_{2}\right)$ sebesar 0,346 menunjukkan bahwa variabel pendapatan memiliki pengaruh positif terhadap kesejahteraan atau tingkat konsumsi; bila pendapatan dinaikkan per Rp. 1 juta maka akan meningkatkan konsumsi sebesar Rp. 346.000, dengan asumsi variabel pendapatan dianggap konstan.

\section{Pembuktian Hipotesis}

Hipotesis dalam penelitian ini diuji dengan menggunakan uji t (uji parsial) serta uji F (uji simultan).

Hasil uji t (uji parsial) untuk variabel jumlah anggota keluarga memperoleh nilai sig. t lebih kecil dari $\alpha(0,00<0,05)$, sehingga dapat dinyatakan bahwa jumlah anggota keluarga berpengaruh signifikan terhadap kesejahteraan atau konsumsi pada masyarakat gampong Karang Anyar.

Hasil uji $t$ untuk variabel pendapatan memperoleh nilai sig. $t$ lebih kecil dari $\alpha(0,00$ $<0,05$ ), sehingga dapat dinyatakan bahwa pendapatan berpengaruh signifikan terhadap kesejahteraan atau konsumsi pada masyarakat gampong Karang Anyar.

Tabel 1. Hasil Analisis Regresi

\begin{tabular}{|c|c|c|c|c|c|c|}
\hline \multirow[t]{2}{*}{ Model } & & \multicolumn{2}{|c|}{ Unstandardized Coefficients } & \multirow{2}{*}{$\begin{array}{c}\text { Standardized } \\
\text { Coefficients }\end{array}$} & \multirow[b]{2}{*}{$\mathrm{t}$} & \multirow[b]{2}{*}{ Sig. } \\
\hline & & $\mathrm{B}$ & Std. Error & & & \\
\hline \multirow[t]{3}{*}{1} & (Constant) & 1258447,865 & 80639,137 & & 15,606 & ,000 \\
\hline & Jumlah anggota keluarga & 422078,720 & 61207,546 & ,743 & 6,896 &, 000 \\
\hline & Pendapatan & ,346 &, 086 & ,250 & 4,023 &, 000 \\
\hline
\end{tabular}

a. Dependent Variable: Konsumsi

Sumber: Data primer (diolah), Tahun 2017. 
Selanjutnya, hasil uji $\mathrm{F}$ atau uji secara simultan memperoleh nilai Sig. F lebih kecil dari $\alpha(0,00<0,05)$, sehingga dapat dinyatakan bahwa jumlah anggota keluarga dan pendapatan secara simultan berpengaruh signifikan terhadap kesejahteraan atau konsumsi pada masyarakat Gampong Karang Anyar.

Dengan demikian, hipotesis dalam penelitian ini yang menyatakan kondisi sosial ekonomi keluarga secara parsial dan simultan berpengaruh secara signifikan terhadap kesejahteraan keluarga di Gampong Karang Anyar bisa dibuktikan atau dapat diterima.

Terakhir, hasil uji koefisien determinasi $\left(\mathrm{R}^{2}\right)$ memperoleh nilai koefisien determinasi sebesar 0,726. Hasil ini menyatakan bahwa variabel-variabel jumlah anggota keluarga dan pendapatan memiliki kontribusi pada kesejahteraan atau konsumsi pada masyarakat Gampong Karang Anyar sebesar 72,6\%; sementara sisanya sebesar $27,4 \%$ dipengaruhi oleh variabel-variabel lain yang tidak diteliti dalam penelitian ini.

\section{KESIMPULAN}

Berdasarkan hasil analisis regresi dan uji hipotesis diperoleh bahwa jumlah anggota keluarga maupun pendapatan secara parsial memiliki pengaruh positif yang signifikan terhadap kesejahteraan atau konsumsi pada masyarakat Gampong Karang Anyar. Secara simultan, jumlah anggota keluarga maupun pendapatan juga terbukti pengaruh yang signifikan pada tingkat kesejahteraan atau konsumsi pada masyarakat Gampong Karang Anyar.

Berlandaskan kesimpulan yang telah dinyatakan, maka disarankan agar masyarakat dapat meningkatkan pendapatan untuk meningkatkan kondisi sosial ditinjau dari tingkat konsumsi. Hal ini karena konsumsi dipengaruhi oleh pendapatan. Peningkatan pendapatan dapat dilakukan dengan cara berwirausaha. Selain itu, jumlah anggota keluarga yang banyak juga disarankan untuk diberdayakan. Salah satu cara adalah dengan memotivasi anggota keluarga agar aktif belajar, bagi anggota keluarga yang masih dalam proses belajar. Cara yang lain adalah dengan memotivasi anggota keluarga yang tidak sekolah lagi untuk menambah pendapatan keluarga melalui berwirausaha.

\section{DAFTAR PUSTAKA}

Abdulsyani. 2007. Sosiologi, Skematika, Teori dan Terapan. Jakarta: PT. Bumi Aksara.

Badan Pusat Statistik. 2012. Statistik Indonesia. Jakarta.

Basrowi. 2005. Pengantar Sosiologi. Jakarta: Penerbit Ghalia Indonesia.

Case, K.E. dan Fair, R.C. 2007. PrinsipPrinsip Ekonomi. Jakarta: Erlangga.

Furqon. 2009. Statistika Terapan untuk Penelitian. Bandung: Alfabeta.

Ishak, I. 2012. Kajian Indikator Kesejahteraan Keluarga. Paper. Seminar dengan tema Penggunaan Data Hasil Penyelidikan: Daripada Persepsi Ke Realiti". Malaysia: Lembaga Penduduk dan Pembangunan Keluarga Negara.

Kuncoro, M. 2004. Ekonomi Pembangunan. Yogyakarta: UMP YKPN.

Kuswardinah, A. 2007. Ilmu Kesejahteraan

Keluarga. Semarang: Universitas Negeri Semarang Press.

Mankiw, G.N. 2006. Pengantar Ekonomi Makro. Jakarta: Salemba Empat.

Muflikhati, Hartoyo, H., Sumarwan, U., Fahrudin, A. dan Puspitawati, $\mathrm{H}$. 2010. Kondisi Sosial Ekonomi dan Tingkat Kesejahteraan Keluarga: Kasus di Wilayah Pesisir Jawa Barat. Jurnal Ilmu Keluarga dan Konsumsi. Vol. 3, No.1, hal. 1-10.

Nurwati, N. 2008. Pengaruh Kondisi Sosial dan Ekonomi Keluarga terhadap Motivasi Pekerja Anak dalam Membantu Keluarga di Kabupaten Cirebon Jawa Barat. Jurnal Kependudukan Padjajaran. Vol. 10 No. 2, hal. 112-121.

Nitisusastro, M. 2013. Perilaku Konsumen dalam Perspektif Kewirausahaan. Bandung: Alfabeta. 
Pass, C. dan Lowes, B. 2004. Kamus Lengkap Ekonomi. Edisi Kedua. Yogyakarta: BPFE.

Pemerintah Republik Indonesia. 2009. Undang-undang Nomor 52 Tahun 2009 tentang Perkembangan Kependudukan. Jakarta.

Puspawati. 2013. Ketahanan dan Kesejahteraan Keluarga. Bogor: Institut Pertanian Bogor.

Rahardja, P. dan Manurung, M. 2010. Teori Ekonomi Mikro. Jakarta: Lembaga penerbit Universitas Indonesia.

Reksohadiprodo, S. 2000. Ekonomi Lingkungan. Yogyakarta: BPFE.
Sinulingga, S. 2013. Metode Penelitian. Medan: USU Press.

Soekanto, S. 2007. Sosiologi, Suatu Pengantar. Jakarta: PT. RajaGrafindo Persada.

Sumardi. 2004. Pengembangan Kesejahteraan Masyarakat. Bandung: Alfabeta

Sugiyono. 2010. Metode Penelitian. Bandung: Alfabeta.

Todaro, M.P. 2005. Economic Development. Eight Edition. England: Pearson Education Limited.

Wakhid, A. 2008. Pendidikan Versus Kemiskinan. Jurnal Nadwa. Vol. 2, No. 1, hal. 100-109. 